\title{
Prediktor Sindrom Syok Dengue pada Anak di Rumah Sakit Umum Daerah dr. H. Andi Abdurrahman Noor, Tanah Bumbu, Kalimantan Selatan
}

Irma Annisa, ${ }^{1}$ Merry Angeline Halim, ${ }^{1}$ RR Putri Zatalini Sabila, ${ }^{1}$ Atut Vebriasa,,${ }^{1}$ Tety Nidiawati, ${ }^{1}$ I Dewa Gede Ariputra, ${ }^{1}$ Aryono Hendarto, ${ }^{2}$ Nina Dwi Putri ${ }^{2}$

${ }^{1}$ KSM Ilmu Kesehatan Anak Rumah Sakit Umum Daerah dr. H. Andi Abdurrahman Noor

${ }^{2}$ Departemen Ilmu Kesehatan Anak Fakultas Kedokteran Universitas Indonesia/Rumah Sakit Cipto Mangunkusumo, Jakarta

Latar belakang. Efusi pleura merupakan salah satu tanda kebocoran plasma pada pasien demam berdarah dengue (DBD) yang dapat dinilai dengan indeks efusi pleura (IEP). Nilai trombosit, hematokrit, dan IEP dapat digunakan untuk mengidentifikasi keparahan DBD.

Tujuan. Mengetahui perbedaan nilai trombosit, hematokrit, dan IEP antara pasien anak yang didiagnosis dengan sindrom syok dengue (SSD) dan DBD tanpa syok.

Metode. Penelitian ini merupakan studi observasional analitik dengan desain cross-sectional. Sampel penelitian ini adalah anak usia 1 bulan-14 tahun. Analisis statistik bivariat dilakukan untuk mencari hubungan antara nilai trombosit, persentase hemokonsentrasi, dan IEP dengan kejadian SSD. Selanjutnya, dilakukan analisis multivariat dengan uji regresi logistik.

Hasil. Hemokonsentrasi berperan secara signifikan sebagai preditor SSD ( $\mathrm{p}=0,001$ dan OR 1,102). Nilai IEP tidak bermakna sebagai prediktor SSD ( $\mathrm{p}=0,052)$, tetapi IEP tetap dimasukkan ke dalam analisis menurut pertimbangan klinis. Sementara itu, angka trombosit tidak terbukti sebagai prediktor SSD dengan $\mathrm{p}=0,549$ dan OR 1,000. Pada kurva ROC didapatkan titik potong skor prediktor SSD adalah $-1,6$ dengan titik potong hemokonsentrasi $23 \%$ dan IEP 25\%. Pada analisis diagnostik titik potong skor prediktor tersebut untuk menilai kejadian SSD didapatkan sensitivitas $92 \%$ dan spesifisitas $83 \%$.

Kesimpulan. Indeks efusi pleura (IEP) bersama dengan hemokonsentrasi dapat digunakan sebagai faktor prediktor kejadian SSD pada anak. Skor prediktor >-1,6 memiliki kemungkinan terjadinya SSD 15,6 kali lebih besar dibandingkan skor prediktor $\leq-1,6$. Sari Pediatri 2021;23(4):228-34

Kata kunci: indeks efusi pleura, trombositopenia, hemokonsentrasi, sindrom syok dengue, demam berdarah dengue

\section{Predictors of Dengue Shock Syndrome in Children at dr. H. Andi Abdurrahman Noor General Hospital, Tanah Bumbu, South Kalimantan}

Irma Annisa, ${ }^{1}$ Merry Angeline Halim, ${ }^{1}$ RR Putri Zatalini Sabila, ${ }^{1}$ Atut Vebriasa, ${ }^{1}$ Tety Nidiawati, ${ }^{1}$ I Dewa Gede Ariputra, ${ }^{1}$ Aryono Hendarto, ${ }^{2}$ Nina Dwi Putri ${ }^{2}$

Background. Pleural effusion is a sign of plasma leakage which can be assessed by the pleural effusion index (PEI). Platelet count, hematocrit, and PEI can be used to identify the severity of dengue hemorrhagic fever (DHF).

Objective. To determine the difference of platelet count, hematocrit, and PEI between pediatric patients diagnosed with dengue shock syndrome (SSD) and DHF without shock.

Methods. This study was an analytic observational study with a cross-sectional design. The sample of this study was children aged 1 month-14 years old. Bivariate statistical analysis was conducted to find the association between platelet count, hemoconcentration level, and PEI with the incidence of SSD. Furthermore, multivariate analysis was performed with a logistic regression test.

Result. Hemoconcentration played a significant role as a predictor of SSD ( $\mathrm{p}=0.001$ dan OR 1,102). PEI was not statistically significant as a predictor of SSD $(\mathrm{p}=0,052)$, but PEI was still included in the analysis according to clinical considerations. Meanwhile, the platelet count was not statistically proven as a predictor of SSD with $\mathrm{p}=0,549$ and OR 1,000. On the ROC curve, the cut-off-point for the SSD predictor score was 1,6 with cut-off-point for hemoconcentration was $23 \%$ and PEI was $25 \%$. Diagnostic analysis of cut-off-point of predictor score to assess the incidence of SSD obtained a sensitivity of $92 \%$ and specificity of $83 \%$.

Conclusion. PEI together with hemoconcentration was able to be used as predictors of the incidence of SSD in pediatric patients. Predictor score of >-1,6 had 15,6 times greater probability of developing SSD than predictor score $\leq-1,6$. Sari Pediatri 2021;23(4):228-34

Keywords: pleural effusion index, thrombocytopenia, hemoconcentration, dengue shock syndrome, dengue hemorrhagic fever

Alamat korespondensi: Irma Annisa. KSM Ilmu Kesehatan Anak RSUD dr. H. Andi Abdurrahman Noor. Jalan. H. M. Amin Km 10 RT 03, Sepunggur, Kusan Hilir, Tanah Bumbu. Email: irma.annisapriyadi@gmail.com 


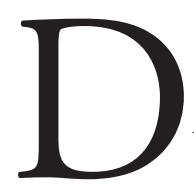
engue merupakan penyakit infeksi yang ditransmisikan oleh gigitan nyamuk spesies Aedes aegypti dan Aedes albopictus. Jumlah kasus dengue yang dilaporkan ke WHO meningkat lebih dari lima belas kali lipat dalam dua dekade terakhir, dari 505.430 kasus pada tahun 2000 hingga melebihi 2.400 .138 pada tahun 2010 dan 3.312.040 pada tahun 2015. Kematian dari tahun 2000 sampai 2015 naik dari 960 menjadi lebih dari 4032. Saat ini, dengue menjadi penyakit endemi di lebih dari seratus negara. Amerika, Asia Tenggara, dan Pasifik Barat merupakan daerah yang paling serius terinfeksi dan Asia merupakan regio yang merepresentasikan $70 \%$ kasus dengue secara global. ${ }^{1}$

Di Indonesia, angka rata-rata kasus dengue tahunan melebihi 129.000 pada periode 2004 sampai 2010 . Angka tersebut merupakan insidensi tertinggi kedua di dunia setelah Brazil. Tujuh provinsi di Indonesia memiliki laju insidensi per 100.000 populasi di atas 100 . Ketujuh provinsi tersebut adalah Bali (484), Kalimantan Timur (306), DKI Jakarta $(198,7)$, Yogyakarta $(167,9)$, Kalimantan Utara $(158,3)$, Sulawesi Tenggara $(123,3)$, dan Kalimantan Selatan $(101,1)$. Menurut studi yang dilakukan oleh Nadjib dkk pada tahun 2015, total biaya tahunan yang dikeluarkan terkait dengue diperkirakan mencapai 381,5 juta dolar Amerika dengan pasien rawat inap menghabiskan biaya sekitar 354,8 juta dolar Amerika, sedangkan biaya untuk pasien rawat jalan sekitar 26,2 juta dolar Amerika. ${ }^{2,3}$ Walaupun laju insidensi kasus dengue di Indonesia meningkat secara signifikan dalam lima dekade, case fatality rate (CFR) tahunan di Indonesia mengalami penurunan. Di akhir tahun 1960, CFR diperkirakan lebih dari 20\% dari pasien yang terinfeksi virus dengue. Angka tersebut berkurang separuhnya setiap dekade sejak tahun 1980 . Pada tahun 2016, CFR hanya 0,79\%. ${ }^{4}$ Akan tetapi, pada pasien yang mengalami syok, mortalitasnya meningkat sampai lebih dari $10 \%$.

Dengue menyebabkan spektrum penyakit yang luas, yaitu dari asimtomatik (flu-like syndrome) atau dikenal dengan demam dengue (DD) sampai manifestasi yang lebih berat dan mengancam nyawa, yaitu demam berdarah dengue (DBD) dan sindrom syok dengue (SSD). ${ }^{5}$ Manifestasi DBD dan SSD merupakan penyebab utama masuk rumah sakit dan mortalitas pada anak. ${ }^{6}$ Sebanyak $14,3 \%$ anak yang terkena infeksi dengue mengalami SSD. Angka tersebut cukup besar bila dibandingkan dengan kasus SSD pada orang dewasa, yaitu 1,6\% dari total kasus dengue pada orang dewasa. ${ }^{7}$ Prognosis DBD dan SSD tergantung dari pencegahan, deteksi awal, dan tata laksana syok. Secara umum, CFR bervariasi, yaitu 2,5-5\%. Saat pasien sudah mengalami syok, mortalitas pasien naik menjadi $12-44 \%{ }^{8}$

Pada awal fase penyakit, gejala pasien dapat tidak spesifik sehingga mengakibatkan tata laksana yang tidak adekuat serta kemungkinan morbiditas dan mortalitas yang lebih tinggi. ${ }^{9,10}$ Jika tidak ditangani dengan baik, infeksi berat dapat berujung pada kematian, terutama pasien anak. Selain itu, untuk daerah pedalaman diagnosis sulit ditegakkan karena tidak adanya fasilitas laboratorium untuk memeriksa parameter untuk penyakit dengue. ${ }^{11}$ Beberapa pemeriksaan yang dinilai krusial untuk memonitor pasien dengue adalah trombosit dan hematokrit, tetapi peran keduanya sebagai prediktor untuk prognosis DBD belum diketahui secara pasti. ${ }^{12-14}$ Efusi pleura merupakan salah satu tanda kebocoran plasma pada pasien DBD. Derajat efusi pleura dinilai dengan Indeks efusi pleura (IEP), yang dapat digunakan untuk menentukan skor kebocoran plasma, mengidentifikasi faktor risiko mortalitas, dan prediktor keparahan DBD. ${ }^{15-18}$

Penelitian ini bertujuan untuk mengetahui perbedaan nilai trombosit, hematokrit, dan IEP antara pasien anak yang didiagnosis dengan SSD dan DBD tanpa syok. Harapannya adalah dapat diketahui faktorfaktor yang berkaitan dengan SSD supaya penanganan pasien anak dengan DBD dapat lebih adekuat sehingga mengurangi angka kejadian SSD pada anak.

\section{Metode}

Penelitian ini merupakan studi observasional analitik dengan desain cross-sectional untuk mengetahui perbedaan nilai trombosit, hematokrit, dan indeks efusi pleura (IEP) antara pasien anak yang didiagnosis dengan sindrom syok dengue (SSD) dan DBD tanpa syok. Penelitian dilakukan di RSUD dr. H. Andi Abdurrahman Noor, Kalimantan Selatan pada bulan Mei-Juli 2020.

Sampel penelitian ini adalah anak usia 1 bulan-14 tahun yang didiagnosis dengan DBD dan berobat di RSUD dr. H. Andi Abdurrahman Noor dari bulan Maret 2019 hingga Juli 2020 dengan kriteria inklusi, yaitu pasien memenuhi kriteria DBD sesuai dengan 
WHO revisi 2011, memiliki data pemeriksaan laboratorium darah perifer lengkap harian saat di rumah sakit dan dilakukan foto rontgen dada right lateral decubitus (RLD). Kriteria eksklusi penelitian adalah anak yang memiliki komorbiditas penyakit lainnya yang dapat memengaruhi prognosis pasien, seperti penyakit jantung bawaan, penyakit ginjal, sirosis hepatis, dan diare dehidrasi berat. Data yang digunakan adalah data sekunder dari rekam medis pada anak dengan bulan Maret 2019 hingga Juli 2020.

Berdasarkan kriteria WHO 2011, DD didiagnosis dengan demam yang disertai minimal dua gejala di antaranya nyeri kepala, nyeri retro-orbital, nyeri otot, nyeri sendi/tulang, ruam kulit makulopapular, dan manifestasi perdarahan (uji bending positif, petekie, purpura, ekimosis, epistaksis, perdarahan gusi, hematemesis, melena), serta tidak ada bukti perembesan plasma. Hasil laboratorium dapat menunjukkan leukopenia, trombositopenia, dan peningkatan hematokrit 5-10\%. Pada DBD derajat I, terdapat bukti perembesan plasma serta laboratorium memperlihatkan trombositopenia dan peningkatan hematokrit $\geq 20 \%$. DBD derajat II merupakan kriteria DBD derajat I ditambah dengan perdarahan spontan. DBD derajat III seperti derajat I atau II ditambah kegagalan sirkulasi (nadi lemah, tekanan nadi $\leq 20 \mathrm{mmHg}$, hipotensi, gelisah). Sementara itu, pada DBD derajat IV, pasien syok hebat dengan tekanan darah dan nadi yang tidak terdeteksi. ${ }^{19}$

Dari masing-masing subjek, dilihat angka trombosit, persentase hemokonsentrasi, dan nilai IEP foto dada. Angka trombosit yang diambil adalah nilai yang terukur pada hari demam ke-5 saat pasien terdapat dalam fase kritis. Persentase hemokonsentrasi dihitung dengan cara mengurangi nilai hematokrit tertinggi selama dirawat di rumah sakit dengan nilai hematokrit minimum selama observasi, kemudian dibagi dengan nilai hematokrit minimum, setelah itu dikali dengan $100 .{ }^{20}$ Indeks efusi

Tabel 1. Karakteristik dasar subjek penelitian

\begin{tabular}{|c|c|c|c|}
\hline \multirow[t]{2}{*}{ Variabel } & \multicolumn{2}{|c|}{$\mathrm{DBD}$} & \multirow[t]{2}{*}{$\mathrm{p}$} \\
\hline & $\operatorname{SSD}(n=58)$ & Tanpa Syok $(\mathrm{n}=17)$ & \\
\hline Berat badan $(\mathrm{kg})$ & $28,31(13,99)$ & $25,55(12,08)$ & $0,596^{*}$ \\
\hline \multicolumn{4}{|c|}{ Kelompok umur (tahun) } \\
\hline$\leq 5$ & $4(25)$ & $12(75)$ & \multirow[t]{2}{*}{$0,519^{* *}$} \\
\hline$>5$ & $13(22)$ & $46(78)$ & \\
\hline \multicolumn{4}{|l|}{ Jenis kelamin } \\
\hline Laki-laki & $10(31,1)$ & $22(68,8)$ & \multirow[t]{2}{*}{$1^{* * *}$} \\
\hline Perempuan & $7(16,3)$ & $36(83,7)$ & \\
\hline \multicolumn{4}{|c|}{ Berat badan (BB)/U } \\
\hline BB kurang & $3(16,7)$ & $15(83,3)$ & \multirow[t]{3}{*}{0,484} \\
\hline BB baik & $10(23,8)$ & $32(76,2)$ & \\
\hline BB lebih & $4(26,7)$ & $11(73,3)$ & \\
\hline \multicolumn{4}{|l|}{ Efusi pleura } \\
\hline Ya & $17(24,6)$ & $52(75,4)$ & \multirow[t]{2}{*}{$0,201^{* *}$} \\
\hline Tidak & $0(0)$ & $6(100)$ & \\
\hline \multicolumn{4}{|c|}{ Perdarahan spontan } \\
\hline Ya & $9(22,5)$ & $31(77,5)$ & \multirow[t]{2}{*}{$1^{* *}$} \\
\hline Tidak & $8(22,9)$ & $27(77,1)$ & \\
\hline \multicolumn{4}{|c|}{ Transfusi trombosit konsentrat } \\
\hline Ya & $13(61,9)$ & $8(38,1)$ & \multirow[t]{2}{*}{$<0,001^{* *}$} \\
\hline Tidak & $4(7,4)$ & $50(92,6)$ & \\
\hline Lama rawat & $5(2-8)$ & $4(1-7)$ & $0,004^{\prime}$ \\
\hline
\end{tabular}

Variabel disajikan sebagai rerata ( $\pm S D$ ) untuk variabel numerik terdistribusi normal, median (minimum-maksimum) untuk variabel numerik terdistribusi tidak normal, atau n (\%) untuk variabel kategorik.

*uji T tidak berpasangan, ${ }^{* *}$ uji Fisher, ${ }^{* * *}$ uji chi square, 'uji Mann-Whitney 
pleura dihitung dengan membagi tebal maksimal efusi pleura dengan lebar maksimal hemitoraks. Kemudian, ditentukan apakah subjek tersebut masuk dalam kelompok SSD atau DBD tanpa syok.

Analisis statistik bivariat dilakukan untuk mencari hubungan antara nilai trombosit, persentase hemokonsentrasi, dan IEP dengan kejadian SSD. Analisis yang digunakan adalah komparatif numerik tidak berpasangan dua kelompok 1x pengukuran. Jika sebaran data normal digunakan uji T tidak berpasangan. Jika sebaran data tidak normal digunakan uji MannWhitney. Selanjutnya, dilakukan analisis multivariat dengan uji regresi logistik. Titik potong skor prediktor untuk kejadian SSD ditentukan dengan kurva receiver operating characteristics (ROC). Analisis statistik tersebut dilakukan dengan program SPSS for Windows versi 25.

\section{Hasil}

Sejak Maret 2020 hingga Juli 2020, terdapat 218 kasus DBD pada anak usia 1 bulan-14 tahun di RSUD dr. H. Andi Abdurrahman Noor. Dari jumlah tersebut, pasien yang memenuhi kriteria inklusi dan lolos dari kriteria eksklusi sebanyak 75 orang. Sampel penelitian dikelompokkan menjadi dua kelompok, yaitu 17 pasien dengan SSD dan 58 pasien dengan DBD tanpa syok.

Tabel 1 Menunjukkan bahwa 79\% pasien berusia $>5$ tahun dan perempuan lebih banyak dibandingkan dengan laki-laki (57\%). Pasien SSD lebih banyak terjadi di kelompok umur $>5$ tahun. Sebagian besar pasien memiliki berat badan (BB) baik (56\%), diikuti dengan BB kurang (24\%), dan terakhir BB lebih (20\%). Rerata BB pasien dengan SSD adalah $28,3 \mathrm{~kg}$, sedangkan pada pasien DBD tanpa syok $25,5 \mathrm{~kg}$.

Efusi pleura terjadi pada pasien SSD $(24,6 \%)$ maupun DBD tanpa syok (75,4\%). Analisis bivariat dengan uji Fisher menunjukkan bahwa tidak ada hubungan yang signifikan antara efusi pleura dengan terjadinya SSD $(p=0,201)$. Selain itu, tidak ada perbedaan yang signifikan manifestasi perdarahan spontan pada pasien dengan SSD dan DBD tanpa syok.

Sebanyak $28 \%$ pasien menerima transfusi trombosit konsentrat (TC), yaitu 61,9\% dengan SSD dan 38,1\% dengan DBD tanpa syok. Uji Fisher menunjukkan terdapat hubungan yang signifikan antara perlunya transfusi trombosit dengan kejadian SSD ( $\mathrm{p}=<0,001)$. Pasien dengan SSD secara signifikan membutuhkan lama waktu rawat yang lebih lama dibandingkan dengan pasien DBD tanpa syok $(\mathrm{p}=0,004)$.

Sebagian besar pasien mengalami DBD derajat II (41,3\%), hanya $22,7 \%$ (17) yang mengalami kejadian SSD. Beberapa pasien diikuti dengan infeksi lainnya, yaitu demam tifoid (3), infeksi saluran kemih (1), bronkiolitis (1), dan pneumonia (1). Komplikasi neurologis ditemukan pada 4 pasien, yaitu 1 pasien dengan kejang demam sederhana (KDS), 2 dengan kejang demam kompleks (KDK), dan 1 pasien dengan ensefalopati dengue. Selain itu, salah satu pasien sudah terdiagnosis autism spectrum disorder (ASD) sebelumnya.

Tabel 2. Nilai trombosit, hematokrit dan indeks efusi pleura (IEP) subjek

\begin{tabular}{lccc}
\hline Variabel & SSD & DBD Tanpa Syok & $\mathrm{p}^{*}$ \\
\hline Trombosit $\left(10^{3} / \mu \mathrm{l}\right)$ & $58,5(27,14) ; 18-129$ & $67,9(143,63) ; 10-61$ & $<0,001$ \\
Hemokonsentrasi $(\%)$ & $42,4(21,34) ; 9,7-83,3$ & $15,3(10,72) ; 0-61,3$ & $<0,001$ \\
IEP $(\%)$ & $40,3(26,50) ; 9-100$ & $19,5(15,43) ; 0-72$ & 0,001 \\
\hline
\end{tabular}

Variabel disajikan sebagai rerata $( \pm S D)$; nilai minimum dan maksimum

*uji Mann-Whitney

Tabel 3. Hasil tes regresi logistik multivariat untuk kategori trombosit, hemokonsentrasi, dan IEP sebagai prediktor SSD

\begin{tabular}{lccccc}
\hline Variabel & $\mathrm{B}$ & S.E. & $\mathrm{p}$ & $\mathrm{OR}$ & $95 \% \mathrm{CI}$ \\
\hline Trombosit $\left(10^{3} / \mu \mathrm{l}\right)$ & $<0,001$ & $<0,001$ & 0,549 & 1,000 & $1,000-1,000$ \\
Hemokonsentrasi $(\%)$ & 0,097 & 0,029 & 0,001 & 1,102 & $1,042-1,166$ \\
IEP $(\%)$ & 0,45 & 0,023 & 0,052 & 1,046 & $1,000-1,094$ \\
Konstanta & $-5,360$ & 1,216 & & & \\
\hline
\end{tabular}

${ }^{*}$ Area under the curve $(A U C)=81 \%(95 \% C I=0,66-0,96)$ 
Irma Annisa dkk: Prediktor sindrom syok dengue pada anak

Tabel 4. Hasil tes regresi logistik multivariat untuk kategori hemokonsentrasi, dan IEP sebagai prediktor SSD

\begin{tabular}{llllll}
\hline Variabel & B & S.E. & p & OR & $95 \%$ CI \\
\hline Hemokonsentrasi (\%) & 0,101 & 0,029 & $<0,001$ & 1,107 & $1,041-1,170$ \\
IEP $(\%)$ & 0,039 & 0,022 & 0,075 & 1,040 & $0,996-1,096$ \\
Konstanta & $-4,871$ & 1,076 & & & \\
${ }^{*}$ Area under the curve $($ AUC $)=90 \%(95 \% C I=0,81-0,98)$ & & &
\end{tabular}

Tabel 5. Hubungan titik potong skor prediktor dengan kejadian SSD

\begin{tabular}{lcccc}
\hline Titik potong skor prediktor & $\begin{array}{c}\text { SSD } \\
\mathrm{n}(\%)\end{array}$ & $\begin{array}{c}\text { Bukan SSD } \\
\mathrm{n}(\%)\end{array}$ & OR & $\mathrm{p}^{*}$ \\
\hline$>-1,6$ & $13(56,5)$ & $10(43,5)$ & 15,6 & $<0,001$ \\
$\leq-1,6$ & $4(7,7)$ & $48(92,3)$ & & \\
\hline${ }^{*}$ uji chi-square & & & &
\end{tabular}

Tabel 2. menunjukkan rerata hasil pemeriksaan laboratorium pada pasien anak DBD. Rerata nilai trombosit pasien dengan SSD lebih rendah dibandingkan dengan pasien DBD tanpa syok $(\mathrm{p}=<0,001)$. Sementara itu, derajat hemokonsentrasi dan IEP pada pasien SSD lebih tinggi dibandingkan dengan DBD tanpa syok $(\mathrm{p}<0,001)$. Sebagian besar pasien dilakukan pemeriksaan RLD pada hari demam ke-5 (48). Sementara sisanya, pasien diperiksa pada hari demam ke-4 (12), ke-6 (11), ke-7 (3), dan ke-8 (1).

Tabel 3 memperlihatkan hasil analisis multivariat regresi logistik untuk kategori trombosit, derajat hemokonsentrasi, dan IEP. Hasil tersebut menunjukkan bahwa hemokonsentrasi berperan secara signifikan sebagai prediktor SSD ( $\mathrm{p}=0,001$ dan OR 1,102$)$. Nilai IEP tidak signifikan sebagai prediktor SSD $(\mathrm{p}=0,052)$, tetapi tetap dimasukkan dalam analisis. Sementara itu, angka trombosit tidak terbukti sebagai prediktor SSD dengan $\mathrm{p}=0,549$ dan OR 1,000. Untuk itu, analisis selanjutnya hanya melibatkan hemokonsentrasi dan IEP.

Tabel 4 menunjukkan hasil uji regresi logistik untuk kategori hemokonsentrasi dan IEP. Pada Tabel 5 didapatkan titik potong skor prediktor SSD adalah -1,6 dengan titik potong hemokonsentrasi $23 \%$ dan IEP $25 \%$. Pada analisis diagnositik titik potong skor prediktor tersebut untuk menilai kejadian SSD didapatkan sensitivitas $92 \%$, spesifisitas $83 \%$, likelihood ratio positive 5,4 , likelihood ratio negative 0,1 , positive predictive value (PPV) 56\%, negative predictive value 92\%.

\section{Pembahasan}

Dalam penelitian kami, sebagian besar pasien mengalami DBD derajat II. Hanya 22,7\% yang mengalami kejadian SSD. Sindrom syok dengue merupakan manifestasi berat pada infeksi virus dengue dan dapat terjadi akibat kebocoran plasma yang tidak tertangani dengan adekuat. Mortalitas pasien meningkat menjadi 12-44\% apabila pasien mengalami syok. Penanganan yang baik pada pasien DBD menurunkan insidensi SSD. Prognosis DBD tergantung dari penanganan awal dan deteksi dini pasien risiko syok.

Perdarahan adalah salah satu komplikasi yang berhubungan dengan mortalitas pasien DBD maupun SSD. Perdarahan terjadi lebih sering pada pasien trombositopenia berat yaitu $<20.000 / \mathrm{mm}^{3}$. Akan tetapi, tidak ada perbedaan manifestasi perdarahan spontan pada pasien dengan SSD dan DBD tanpa syok. Perdarahan spontan dapat terjadi pada pasien dengan DBD derajat II maupun pasien SSD. ${ }^{19}$

Untuk pasien DBD diperlukan tranfusi trombosit apabila terjadi perdarahan ataupun dibutuhkan transfusi profilaksis jika jumlah trombosit $<20.000 .{ }^{21}$ Tranfusi profilaksis trombosit meningkat di daerah endemis. ${ }^{22}$ Pada penelitian kami, 61,9\% pasien yang menerima transfusi TC adalah pasien dengan SSD. Uji Fisher menunjukkan terdapat hubungan antara transfusi trombosit dengan kejadian SSD. Pasien dengan SSD membutuhkan waktu rawat yang lebih lama dibandingkan dengan pasien DBD tanpa syok. 
Hasil analisis dengan uji Mann-Whitney memperlihatkan bahwa rerata nilai trombosit pada pasien dengan SSD lebih rendah dibandingkan dengan pasien DBD tanpa syok. Hal tersebut sejalan dengan penelitian dari Khan $\mathrm{dkk}^{23}$ yang mengatakan bahwa derajat trombositopenia memiliki hubungan dengan derajat infeksi virus dengue. Penelitian yang dilakukan oleh Lam $\mathrm{dkk}^{12}$ juga menunjukkan bahwa nilai trombosit yang rendah merupakan salah satu faktor risiko terjadinya SSD pada uji univariat dan multivariatnya. Penelitian tersebut mengatakan bahwa observasi nilai trombosit harian dapat berguna untuk memprediksi prognosis pasien. Akan tetapi, nilai prognostik tersebut terbatas waktu. Artinya, nilai trombosit hari ini dapat berguna untuk menilai risiko kejadian SSD dalam waktu 24 jam selanjutnya, namun tidak dapat digunakan untuk memprediksi risiko SSD dalam 2-3 hari selanjutnya.

Derajat hemokonsentrasi berperan sebagai prediktor SSD. Pada penelitian kami didapatkan hasil bahwa derajat hemokonsentrasi pada pasien SSD lebih tinggi dibandingkan dengan pasien DBD tanpa syok. Hal tersebut sesuai dengan penelitian Setiati $\mathrm{dkk}^{16}$ yang menunjukkan bahwa rerata nilai hematokrit pasien SSD, yaitu $41,8 \%$, lebih tinggi dibandingkan nilai rerata pasien anak DBD tanpa syok, yaitu 38,8\%. Tingginya hematokrit menunjukkan hemokonsentrasi yang lebih besar dan bermanifestasi sebagai kebocoran plasma. Kebocoran plasma dapat menimbulkan hilangnya volume intravaskular dan insufisiensi sirkulasi.

Hal ini juga sejalan dengan penelitian dari Cecilia \& Sugianto pada tahun 2019 di Surabaya. ${ }^{24}$ Meskipun tidak mengukur derajat hemokonsentrasi, penelitian Cecilia dan Sugianto menunjukkan bahwa nilai hematokrit tinggi merupakan salah satu prediktor SSD. Di Penelitian lainnya, Mulyaningrum dan Wardani ${ }^{25}$ tahun 2016 di Yogyakarta, melaporkan bahwa nilai hematokrit $>45 \%$ merupakan prediktor terhadap terjadinya SSD. Oleh sebab itu, peneliti menggunakan derajat hemokonsentrasi menjadi salah satu variabel untuk menentukan skor prediktor SSD.

Nilai IEP pasien dengan SSD lebih besar dibanding pasien dengan DBD tanpa syok. Hal ini sesuai dengan penelitian yang dilakukan oleh Kustiah ${ }^{26}$ pada tahun 2011 di Semarang yang menyatakan bahwa rerata IEP pada kelompok SSD lebih tinggi dibanding non SSD. Selain itu, penelitian lainnya juga memperlihatkan bahwa pasien dengan IEP $>9 \%$ berisiko enam kali lebih besar untuk mengalami SSD dibanding IEP 9\%. ${ }^{18}$ Hasil penelitian kami juga sejalan dengan penelitian Setiati $\mathrm{dkk}^{16}$ yang melaporkan nilai IEP merupakan salah satu faktor risiko terjadinya SSD. Pada penelitian kami, sebagian besar pasien dilakukan pemeriksaan RLD pada hari ke-5 (64\%). Hari ke-5 dianggap sebagai waktu yang paling tepat untuk melihat kebocoran plasma sebab kebocoran plasma terjadi dalam waktu 24-48 jam setelah demam turun (setelah hari ke-3). ${ }^{15}$

Akan tetapi, berdasarkan analisis multivariat, nilai IEP tidak didapatkan sebagai prediktor SSD. Hal ini mungkin disebabkan karena jumlah sampel SSD yang sedikit. Namun, karena pada analisis univariat IEP didapatkan bermakna dan IEP juga merupakan representatif kejadian efusi pleura maka variabel IEP tetap dimasukkan dalam analisis selanjutnya. Sementara itu, nilai trombosit tidak didapatkan sebagai prediktor SSD sehingga tidak dimasukkan dalam analisis selanjutnya.

Setelah dilakukan analisis regresi logistik dengan kategori derajat hemokonsentrasi dan IEP didapatkan formulasi skor prediktor (Skor prediktor $=-4,871$ $+(0,101 \times$ hemokonsentrasi $)+(0,039 \times$ IEP $)$, yang dapat digunakan dalam tata laksana DBD untuk meningkatkan kewaspadaan dan antisipasi terjadinya SSD. Titik potong derajat hemokonsentrasi $23 \%$ dan IEP 25\% dianggap sebagai titik potong skor prediktor SSD. Skor prediktor ini memiliki sensitivitas yang cukup tinggi sehingga diharapkan dapat menjadi salah satu modalitas untuk mengantisipasi terjadinya SSD pada anak dengan DBD.

Keterbatasan penelitian kami adalah jumlah subjek penelitian kami sedikit dan kami tidak menilai hubungan antara status gizi dengan kejadian SSD, dimana status gizi berhubungan dengan sistem imunitas seluler, integritas respon imunitas seluler yang berkorelasi dengan DBD/SSD. Hal tersebut disebabkan oleh keterbatasan data yang kami dapatkan dari rekam medis pasien.

\section{Kesimpulan}

Indeks efusi pleura (IEP) bersama dengan hemokonsentrasi dapat digunakan sebagai faktor prediktor kejadian SSD pada anak. Skor prediktor >-1,6 memiliki kemungkinan terjadinya SSD 15,6 kali lebih besar dibandingkan skor prediktor $\leq-1,6$. Diperlukan penelitian lanjutan dengan jumlah pasien lebih banyak supaya skor prediktor lebih akurat. 
Irma Annisa dkk: Prediktor sindrom syok dengue pada anak

\section{Daftar pustaka}

1. WHO. Dengue and severe dengue [Internet]. [cited 2020 Jul 30]. Didapat dari: https://www.who.int/news-room/fact-sheets/ detail/dengue-and-severe-dengue.

2. Nadjib M, Setiawan E, Putri S, dkk. Economic burden of dengue in Indonesia. PLoS Negl Trop Dis 2019;13(1):1-14.

3. Haryanto B. Indonesia dengue fever: status, vulnerability, and challenges. Dalam: Current topics in tropical emerging diseases and travel medicine. London: Intech Open; 2018.h.81-92.

4. Harapan H, Michie A, Mudatsir M, dkk. Epidemiology of dengue hemorrhagic fever in Indonesia: analysis of five decades data from the National Disease Surveillance. BMC Res Notes 2019;12:350.

5. WHO. Comprehensive guidelines for prevention and control of dengue and dengue haemorrhagic fever [Internet]. WHO Regional Publication SEARO. 2011. 159-168 p. Didapat dari: http://scholar.google. com/scholar?hl=en\& $b t n G=$ Search\& $q=$ intitle :Comprehensive + Guidelines + for + Prevention + and + Control + of + Dengue +and+Dengue+Haemorrhagic+Fever\#1.

6. Alejandria MM. Dengue haemorrhagic fever or dengue shock syndrome in children. BMJ Clin Evid 2015;2015:1-15.

7. Anders KL, Nguyet NM, Chau NVV, dkk. Epidemiological factors associated with dengue shock syndrome and mortality in hospitalized dengue patients in Ho Chi Minh City, Vietnam. Am J Trop Med Hyg 2011;84:127-34.

8. Rigau-Pérez JG, Clark GG, Gubler DJ, Reiter P, Sanders EJ, Vorndam AV. Dengue and dengue haemorrhagic fever. The Lancet 1998;352:971-7.

9. Phakhounthong K, Chaovalit P, Jittamala P, dkk. Predicting the severity of dengue fever in children on admission based on clinical features and laboratory indicators: Application of classification tree analysis. BMC Pediatr 2018;18:1-9.

10. Tanner L, Schreiber M, Low JGH, dkk. Decision tree algorithms predict the diagnosis and outcome of dengue fever in the early phase of illness. PLoS Negl Trop Dis 2008;2:1-9.

11. Potts JA, Thomas SJ, Srikiatkhachorn A, dkk. Classification of dengue illness based on readily available laboratory data. Am J Trop Med Hyg 2010;83:781-8.

12. Lam PK, Ngoc T Van, Thu Thuy TT, dkk. The value of daily platelet counts for predicting dengue shock syndrome: Results from a prospective observational study of 2301 Vietnamese children with dengue. PLoS Negl Trop Dis 2017;11:1-20.

13. Huy NT, Van Giang T, Thuy DHD, dkk. Factors associated with dengue shock syndrome: a systematic review and metaanalysis. PLoS Negl Trop Dis 2013;7:1-15.

14. Yacoub S, Wills B. Predicting outcome from dengue. BMC Med 2014;12:1-10.

15. Kusumaningtias A, Hapsari M, Satoto B. Korelasi pleural effusion index dengan jarak interpleura secara ultrasonografi pada demam berdarah dengue anak. Sari Pediatri 2015;16:337-41.

16. Setiati TE, Retnaningsih A, Supriatna M, Soemantri A. Skor kebocoran vaskuler sebagai prediktor awal syok pada demam berdarah dengue. J Ked Brawijawa. 2005;21:16-21.

17. Hawarini N, Kosim M, Supriatna M, Istanti Y, Sudijanto E. The relationship between pleural effusion index and mortality in children with dengue shock syndrome. Paediatr Indones 2012;52:239-42.

18. Cahyaningrum J. Indeks efusi pleura sebagai prediktor sindrom syok dengue pada anak di RSUD Dr. Moewardi Surakarta. J Ked Indon 2009;1:32-9.

19. WHO. Comprehensive guidelines for prevention and control of dengue and dengue haemorrhagic fever. WHO Regional Publication SEARO. New Delhi: WHO Regional Publication SEARO; 2011.

20. Suwarto S, Nainggolan L, Sinto R, dkk. Dengue score: A proposed diagnostic predictor for pleural effusion and/or ascites in adults with dengue infection. BMC Infect Dis 2016;16:1-7. doi.org/10.1186/s12879-016-1671-3.

21. Makroo R, Raina V, Kumar P, Kanth R. Role of platelet transfusion in the management of dengue patients in a tertiary care hospital. Asian J Transfus Sci 2007;1:4.

22. Kaur P, Kaur G. Transfusion support in patients with dengue fever. Int J Appl Basic Med Res 2014;4:8.

23. Mohamed Khan D, Kuppusamy K, Sumathi S, Mrinalini VR. Evaluation of thrombocytopenia in dengue infection along with seasonal variation in rural melmaruvathur. J Clin Diagnostic Res 2014;8:39-42.

24. Cecilia C, Sugianto JA. Predictor of dengue shock syndrome among pediatric dengue infection in limited resource setting. J Indon Med Assoc 2019;69:178-83.

25. Mulyaningrum U, Wardani K. Clinical and hematological parameters as the predictors of shock in dengue infection. Glob Med Heal Commun 2018;6:176-81.

26. Kustiah AR, Soemantri A. Hubungan faktor kebocoran vaskuler dengan disfungsi paru pada demam berdarah dengue. Sains Medika 2011;3:1-15. 